\title{
Жіноча стать як фактор прогнозу виживаності хворих на низькодиференційований рак сечового міхура після хірургічного лікування
}

\author{
${ }^{1}$ Національний медичний університет імені О.О. Богомольця, Київ \\ ${ }^{2}$ Київський національний університет імені Т.Г. Шевченка, Київ \\ Одержано: 30.07.2019 \\ Прийнято до друку: 7.10.2019 \\ DOI: 10.32471/clinicaloncology.2663-466X.38.22980
}

\begin{abstract}
Рак сечового міхура - злоякісне новоутворення, яке переважно відмічають у населення чоловічої статі. Проте вважається, що у жінок це захворювання протікає більш агресивно та показники виживаності нижчі, ніж у чоловіків. Мета. Визначити статеві відмінності узахворюваності на найагресивнішу форму раку сечового міхура, низькодиференційований рак, та показники виживаності хворих обох статей залежно від клінічної стадії хвороби та методу проведеного радикального хірургічного лікування. Матеріали та методи. Ретроспективний аналіз історій хвороб 364 пацієнтів із низькодиференційованим раком сечового міхура (чоловіків 305, жінок 59, співвідношення чоловіків і жінок - 5,2:1), які проходили хірургічне лікування в 2004-2017 рр. 3 метою виявлення статистично значущої кореляції між статтю пацієнта та результатами виживаності залежно від клінічної стадії хвороби (I, II, III та IV) та методу хірургічного лікування (трансуретральна резекція, резекція, радикальна цистектомія). Результати. Зі збільшенням клінічної стадії раку кількість захворілих жінок зменшується зворотно пропорційно стадії раку. Занедбаних випадків раку серед жінок не було. Виявлена статистично значуща і достовірна відмінність між кривими виживаності хворих із IV стадією низькодиференційованого раку сечового міхура $(p=0,035)$ в бік кращої виживаності жінок. При раку стадії I та проведенні трансуретральної резекції сечового міхура відмінностей між кривими виживаності як візуально, так і на підставі статистичних розрахунків $(p=0,738)$ немає. При стадіях II, III та при проведенні резекції міхура та радикальної цистектомії криві виживаності жінок є вищими за такі чоловіків, критерій р наближається до порога значущості $(p=0,102)$. Збільшення вибірки хворих, особливо за рахунок пацієнтів жіночої статі, зможе покращити точність аналізу. Висновки. Захворюваність на низькодиференційований рак сечового міхура та смертність від нього має чітку статеву залежність від стадії раку в бік переважання чоловічого фактора. Результати 5- та 10-річної виживаності жінок 3 низькодиференційованим раком сечового міхура є кращими порівняно з чоловіками. При проведенні аналізу виживаності за методом Каплана - Мейєра залежно від клінічної стадії низькодиференційованого раку сечового міхура та методу хірургічного лікування виявлена статистично значима відмінність лише між кривими виживаності хворих із IV стадією в бік кращої виживаності жінок. При інших стадіях та методах лікування криві виживаності жінок $є$ вищими за такі серед чоловіків, проте статистичної значущості ці відмінності не мали.
\end{abstract}

Ключові слова: рак сечового міхура, низькодиференційований рак, хірургічне лікування, виживаність, статеві відмінності.

\section{ВСТУП}

Рак сечового міхура (РСM) - злоякісне новоутворення, що розвивається з епітелію сечового міхура та уражає переважно чоловіче населення зі співвідношенням захворілих чоловіків до жінок як 3-4:1 [1]. Проте вважається, що РСМ у жінок протікає більш агресивно та показники виживаності гірші, ніж у чоловіків [1-11]. На момент встановлення первинного діагнозу РСМ у жінок виявляється на більш занедбаній стадії, ніж у чоловіків, і прогноз виживаності після проведення радикальної цистектомії, відповідно, є гіршим [12]. Пояснень цього феномену є декілька. РСМ не $€$ поширеною хворобою серед представниць жіночої статі. Тому у разі появи симптомів раку (гематурія, дизурія), що притаманні й неспецифічним інфекційним захворюванням сечових шляхів, РСМ не стоїть на першому місці в диференційній діагностиці, що й призводить до затримки зі встановленням коректного діагнозу [13]. Анатомічні особливості, активність ферментів метаболізму статевих гормонів та ксенобіотиків, гормональний фон, експресія рецепторів до андрогенів та естрогенів також можуть мати вплив на захворюваність та протікання РСМ [14-17].

\section{META}

Визначити статеві відмінності у захворюваності на найагресивнішу форму РСМ, низькодиференційований рак, та показники виживаності хворих обох статей залежно від клінічної стадії хвороби та методу проведеного радикального хірургічного лікування.

\section{МАТЕРІАЛИ ТА МЕТОДИ}

Проведений ретроспективний аналіз історій хвороб пацієнтів на низькодиференційований РСМ, які проходили хірур- гічне лікування в умовах урологічного відділення Київського міського клінічного онкологічного центру та кафедри онкології Національного медичного університету ім. О.О. Богомольця за період 2004-2017 рр. з метою виявлення статистично значущої кореляції між статтю пацієнта (чоловік, жінка) та результатами виживаності залежно від клінічної стадії хвороби (I, II, III i IV) та методу хірургічного лікування (трансуретральна резекція, резекція, радикальна цистектомія). Клінічна стадія РСМ була встановлена на підставі класифікації Американського об'єднаного комітету з вивчення раку (American Joint Committee on Cancer - AJCC) [18]. Соматичний статус хворих оцінювався відповідно до Шкали оцінки загального стану онкологічного хворого (Eastern Cooperative Oncology Group Performance Status) [19]; усі хворі, яким було заплановано хірургічне втручання, мали ECOG-статус не вище за 0-1. Методи статистичної обробки даних включали побудову кривих виживаності за методом Каплана - Мейєра для визначення статистично значимих відмінностей між кривими виживаності хворих на низькодиференційований РСМ за групами, а саме залежно від клінічної стадії хвороби та від методу хірургічного лікування. Перевірка гіпотези про аналогічність показників виживаності хворих обох статей (двох функцій виживаності) залежно від клінічної стадії раку та методу хірургічного лікування виконувалася за допомогою 3 статистичних критеріїв (log-rank, Wilcoxon, Tarone - Ware) при рівні значущості 0,05. Результати відмінностей між кривими виживаності вважалися значущими, якщо значення $p$ було менше за $0,05(p<0,05)$. Статистична обробка даних виконувалася за допомогою програмного забезпечення Microsoft Excel та XLSTAT. 


\section{Оригінальні статті / Original Articles}

\section{РЕЗУЛЬТАТИ}

За означений період ретроспективного аналізу було проліковано 364 хворих на низькодиференційований РСМ. Серед них чоловіків було 305 , жінок -59 , співвідношення чоловіків до жінок становило 5,2:1. Середній вік хворих статистично не відрізнявся між групами за статтю та стадією хвороби, у чоловіків він був $63 \pm 4,8$ роки, у жінок $-62 \pm 3,8$ роки. Статистично достовірних відмінностей у соматичному статусі та індексі маси тіла (IMT) хворих між групами за статтю та стадією хвороби виявлено не було, у всіх хворих визначали статус ECOG на рівні $0-1$, IMT $-26,3 \pm 0,8$ у чоловіків та 26,9 $1,1-$ у жінок. Середній термін спостереження за хворими становив 93 міс (1,0-226,0 міс). На час проведення цього дослідження $61 \%$ хворих померли від прогресування хвороби. Розподіл пацієнтів за статтю, стадією РСМ та виживаністю представлений у табл. 1.

Як можна побачити з табл. 1, зі збільшенням клінічної стадії низькодиференційованого РСМ кількість захворілих жінок зменшується зворотно пропорційно стадії раку. При стадії I на одну захворілу жінку з низькодиференційованим РСМ припадало 2,7 пацієнта чоловічої статі, а при стадії IV співвідношення було 8,1 чоловіків на 1 жінку. Тобто хворих із занедбаним РСМ було більше серед осіб чоловічої статі. Загальний огляд результатів виживаності хворих обох статей при кожній зі стадій низькодиференційованого РСМ вказує на дещо кращі показники при стадіях I та III у чоловіків, 56 проти $50 \%(p=0,705)$ та 29 проти $28 \%$ $(p=0,585)$ при відповідних стадіях. При стадіях II та IV, навпаки, виживаність у чоловіків $\epsilon$ гіршою, а саме 40 проти $61 \%(p=0,102)$ та 12 проти $43 \%(p=0,035)$ при відповідних стадіях. Тобто у разі занедбаної стадії РСМ, стадії IV, виживаність хворих жіночої статі $€$ статистично достовірно кращою.

Розподіл хворих на низькодиференційований РСМ за методами лікування, за статтю та виживаністю представлений у табл. 2.

Огляд даних, представлених у табл. 2, вказує на те, що переважним методом лікування серед хворих чоловічої статі була радикальна цистектомія (35\% усіх хірургічних втручань), а серед жінок - трансуретральна резекція (54\% усіх операцій у жінок). Біопсію сечового міхура як єдиний метод хірургічного втручання виконували лише у чоловіків (5,9\% усіх операцій), що вказує на те, що занедбаних інкурабельних випадків низькодиференційованого РСМ було більше серед пацієнтів чоловічої статі іжодного - серед жінок. Результати виживаності у розрізі методів хірургічного лікування вказують на те, що при будь-якому методі хірургічного втручання сукупні показники виживаності серед жінок були вищими, ніж серед чоловіків.

Таблиця 1. Розподіл хворих на низькодиференційований РСМ за статтю, стадією та виживаністю на момент дослідження

\begin{tabular}{|c|c|c|c|c|c|c|c|c|c|c|}
\hline \multirow{2}{*}{ Стадія РСМ } & \multicolumn{4}{|c|}{ Чоловіки } & \multicolumn{4}{|c|}{ Жінки } & \multirow{2}{*}{ Загалом } & \multirow{2}{*}{ Співвідношення чоловік:жінка } \\
\hline & Загалом & Померлі & Живі & Живі, \% & Загалом & Померлі & Живі & Живі, \% & & \\
\hline I & 16 & 7 & 9 & 56,3 & 6 & 3 & 3 & 50,0 & 22 & $2,7: 1$ \\
\hline II & 130 & 78 & 52 & 40,0 & 28 & 11 & 17 & 60,7 & 158 & $4,6: 1$ \\
\hline III & 102 & 72 & 30 & 29,4 & 18 & 13 & 5 & 27,8 & 120 & $5,7: 1$ \\
\hline IV & 57 & 50 & 7 & 12,3 & 7 & 4 & 3 & 42,9 & 64 & $8,1: 1$ \\
\hline Загалом & 305 & 207 & 98 & 32,1 & 59 & 31 & 28 & 47,5 & 364 & $5,2: 1$ \\
\hline
\end{tabular}
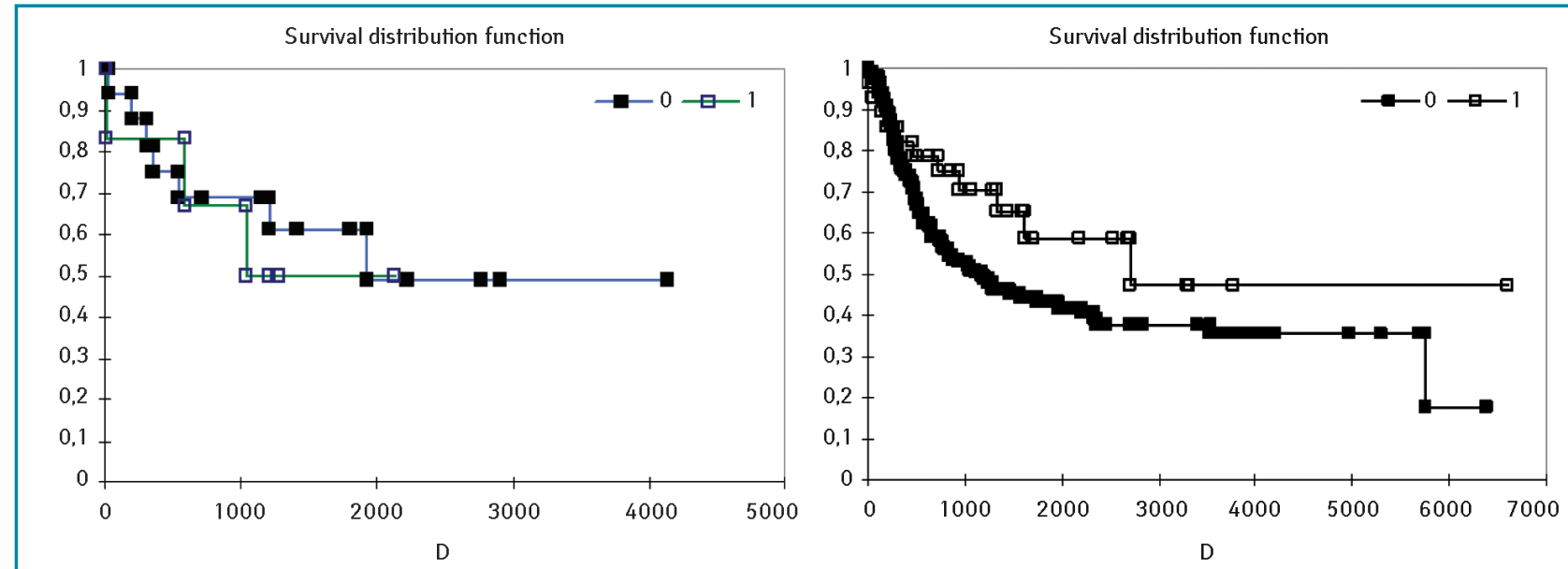

А. Стадія I низькодиференційованого PCM, p=0,705 (Wilcoxon)

Б. Стадія II низькодиференційованого РСМ, p=0,102 (log-rank)
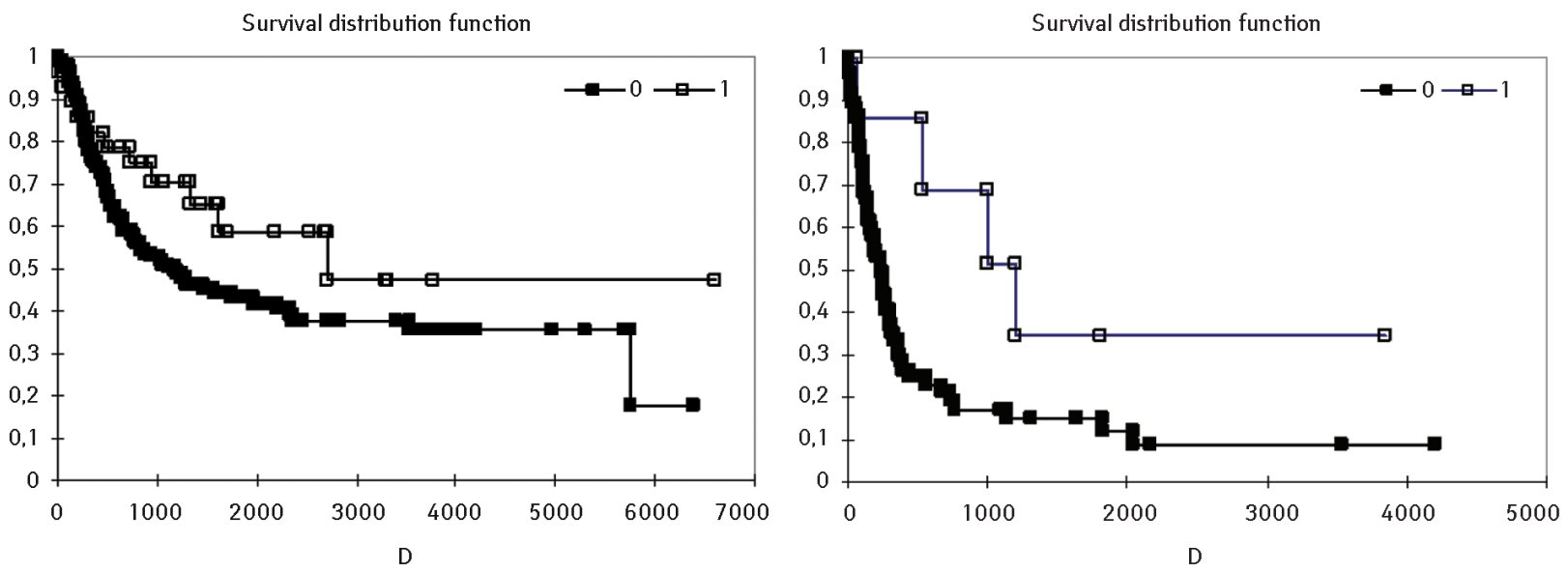

В. Стадія III низькодиференційованого РСM, $p=0,585$ (Wilcoxon)

Г. Стадія IV низькодиференційованого PCM, $p=0,035$ (Tarone - Ware)

Рис. 1. Криві виживаності Каплана - Мейєра хворих на низькодиференційований РСМ залежно від статі та клінічної стадії. 0 - чоловіки, 1 - жінки 
Оригінальні статті / Original Articles

Таблиця 2. Розподіл хворих на низькодиференційований РСМ за методами лікування, статтю та виживаністю на момент дослідження

\begin{tabular}{|c|c|c|c|c|c|c|c|c|c|c|c|}
\hline \multirow{2}{*}{$\begin{array}{c}\text { Методи хірургіч- } \\
\text { ного лікування }\end{array}$} & \multicolumn{5}{|c|}{ Чоловіки } & \multicolumn{5}{|c|}{ Жінки } & \multirow[b]{2}{*}{ Загалом } \\
\hline & Загалом & $\begin{array}{c}\text { Метод } \\
\text { лікування, \% }\end{array}$ & Померло & Живі & Живі, \% & Загалом & $\begin{array}{c}\text { Метод } \\
\text { лікування, \% }\end{array}$ & Померло & Живі & Живі, \% & \\
\hline $\begin{array}{l}\text { Трансуретральна } \\
\text { резекція }\end{array}$ & 104 & 34,1 & 62 & 42 & 40,4 & 32 & 54,2 & 18 & 14 & 43,8 & 136 \\
\hline Резекція & 76 & 24,9 & 53 & 23 & 30,3 & 20 & 33,9 & 10 & 10 & 50,0 & 96 \\
\hline $\begin{array}{l}\text { Радикальна } \\
\text { цистектомія }\end{array}$ & 107 & 35,1 & 74 & 33 & 30,8 & 7 & 11,9 & 3 & 4 & 57,1 & 114 \\
\hline $\begin{array}{l}\text { Біопсія } \\
\text { Загалом }\end{array}$ & $\begin{array}{c}18 \\
305\end{array}$ & $\begin{array}{l}5,9 \\
100\end{array}$ & $\begin{array}{c}18 \\
207\end{array}$ & $\begin{array}{c}0 \\
98\end{array}$ & $\begin{array}{c}0,0 \\
32,1\end{array}$ & $\begin{array}{c}0 \\
59\end{array}$ & $\begin{array}{c}0,0 \\
100,0\end{array}$ & $\begin{array}{c}0 \\
31\end{array}$ & $\begin{array}{c}0 \\
28\end{array}$ & $\begin{array}{c}0,0 \\
47,5\end{array}$ & $\begin{array}{c}18 \\
364\end{array}$ \\
\hline
\end{tabular}

Нарис. 1 наведені криві виживаності за Капланом - Мейєром для пацієнтів чоловічої та жіночої статі залежно від клінічної стадії (I, II, III та IV) низькодиференційованого РСМ з оцінкою достовірності різниці у виживаності $p$ за трьома статистичним критеріями, наведений статистичний критерій 3 найнижчим значенням $p$.

На рис. 2 наведені криві виживаності за Капланом - Мейєром для пацієнтів чоловічої та жіночої статі залежно від методу хірургічного лікування низькодиференційованого РСМ.

При проведенні аналізу за методом Каплана - Мейєра, що представлений на рис. 1 та 2, виявлена статистично значима і достовірна відмінність лише між кривими виживаності хворих зі стадією IV низькодиференційованого РСМ з $p<0,05$ за всіма трьома статистичними критеріями. Показники виживаності жінок зі стадією IV РСМ достовірно кращі, ніж у чоловіків. Проте важливо відмітити незбалансованість вибірки хворих стадії IV - 57 чоловіків та всього 7 жінок. При раку стадії I відмінностей між кривими виживаності як візуально, так і на підставі статистичних розрахунків $(p=0,738)$ немає. При стадії II, яка $є$ найпоширенішою стадією РСМ, згідно 3 нашими даними, візуально крива виживаності жінок є вищою за криву виживаності у чоловіків, а критерій $p$ наближається до порога значущості $(p=0,102)$.

Під час проведення аналізу відмінності між кривими виживаності залежно від методу хірургічного лікування, виживаність жінок статистично достовірно не відрізнялася від такої чоловіків, проте критерії $p$ наближаються до порога значущості в бік кращої виживаності жінок. Після трансуретральної резекції сечового міхура $(p=0,079)$ криві візуально ідентичні, шо співпадає з результатами виживаності при стадії I РСМ, за якої цей метод хірургічного лікування найчастіше й застосовується. Після резекції та радикальної цистектомії криві виживаності жінок візуально вищі за такі у чоловіків, статистично значущої різниці виявлено не було, хоча значення $p$ наближається до порога достовірності. Збільшення вибірки хворих, особливо за рахунок пацієнтів жіночої статі, зможе підвищити точність аналізу.

Результати 5- та 10-річної виживаності хворих на низькодиференційований РСМ згідно з аналізом кривих за Капланом - Мейєром залежно від стадії хвороби та методу хірургічного лікування представлені в табл. 3.

Аналіз даних табл. 3 вказує на те, що показники 5-річної виживаності при більшості стадій низькодиференційованого РСМ та при кожному з методів хірургічного лікування є кращими серед жінок порівняно з такими серед чоловіків. Результати гіршої виживаності серед жінок при стадії I пов'язані з малою вибіркою, а саме з тим, що зі стадією I у дослідження було залучено лише 6 жінок.

\section{дискусія}

РСМ у світі діагностується в 3-4 рази частіше серед чоловіків, ніж серед жінок $[4,9,15,26]$. Приріст захворюваності на РСМ у світі у чоловіків на 25\% перевищує приріст у жінок протягом останніх десятиліть [27]. Але є чимало свідчень того, шо саме у жінок рак виявляють на більш пізніх стадіях і саме жінки мають гірші прогнози виживаності при РСМ порівняно з чоловіками $[16,23,25]$. РСМ має схильність до більш агресивного перебігу саме у жінок, у них частіше діагностують низькодиференційовані форми раку $[17,26]$, також у них частішим $є$ мультифокальне ураження міхура, а розмір пухлин є більшим [22, 29], крім того, частіше виявляють неуротеліальні форми раку [29], що спричиняє гірший прогноз хвороби. У жінок частіше діагностується місцево-поширений рак на момент встановлення первинного діагнозу [7, 23, 28], а вища стадія

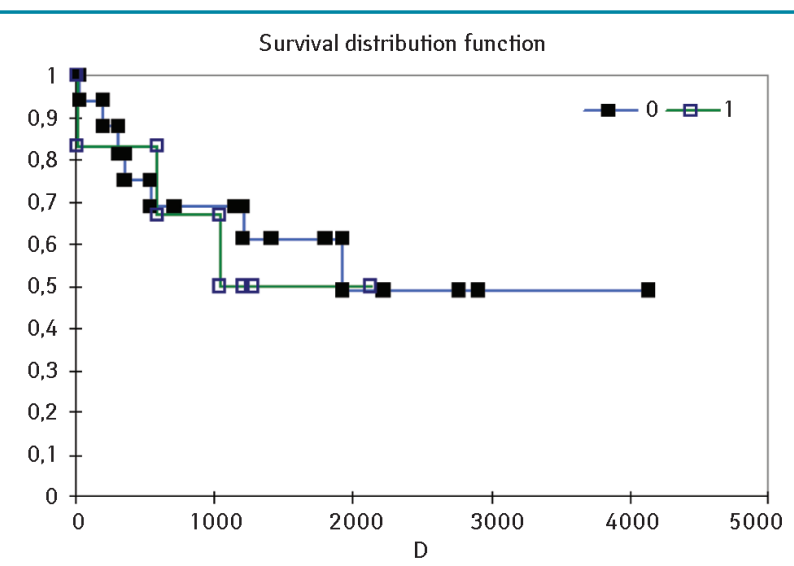

А. Трансуретральна резекція сечового міхура, $p=0,079$ (Wilcoxon)

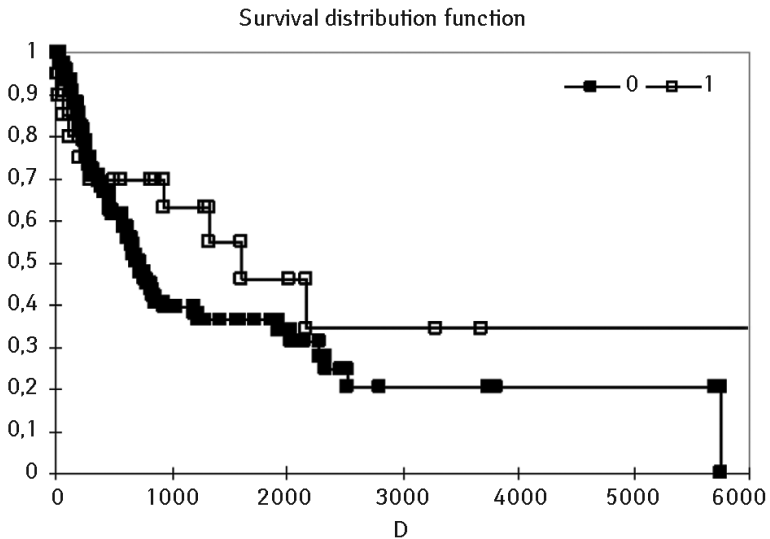

Б. Резекція сечового міхура, $p=0,186$ (log-rank)

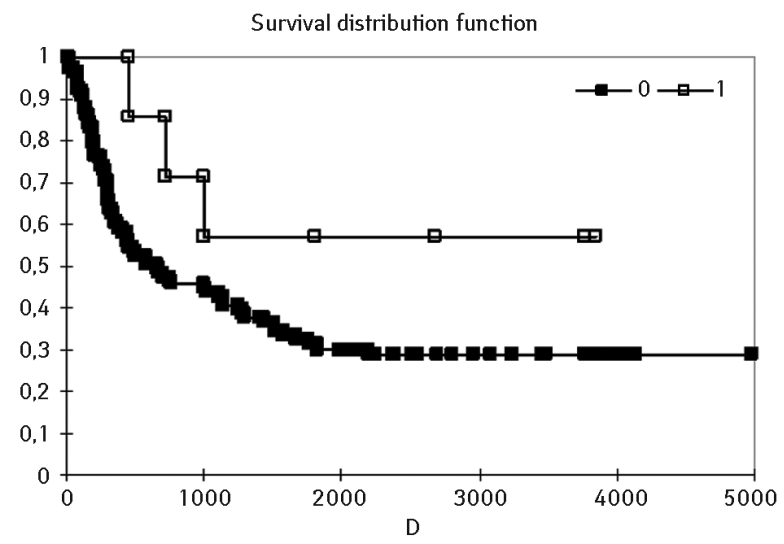

В. Радикальна цистектомія, $p=0,111$ (Tarone - Ware)

Рис. 2. Криві виживаності Каплана - Мейєра хворих на низькодиференційований РСМ чоловічої та жіночої статі залежно від методу хірургічного лікування. 0 - чоловіки, $1-$ жінки 
Таблиця 3. Результати 5- та 10-річної виживаності хворих на низькодиференційований рак сечового міхура залежно від стадії хвороби на методу хірургічного лікування

\begin{tabular}{|c|c|c|c|c|}
\hline \multirow[b]{2}{*}{ Стадія РСМ } & \multicolumn{2}{|c|}{ Чоловіки } & \multicolumn{2}{|c|}{ Жінки } \\
\hline & 5-річна виживаність, \% & 10-річна виживаність, \% & 5-річна виживаність, \% & 10-річна виживаність, \% \\
\hline I & 61 & 49 & 50 & 50 \\
\hline II & 43 & 35 & 59 & 47 \\
\hline III & 30 & 24 & 42 & 10 \\
\hline IV & 12 & 9 & 34 & 34 \\
\hline \multicolumn{5}{|c|}{ Метод хірургічного лікування } \\
\hline Трансуретральна резекція & $39 \%$ & $31 \%$ & $50 \%$ & $13 \%$ \\
\hline Резекція & $36 \%$ & $20 \%$ & $46 \%$ & $36 \%$ \\
\hline Радикальна цистектомія & $30 \%$ & $28 \%$ & $57 \%$ & $57 \%$ \\
\hline
\end{tabular}

на момент виявлення раку є незалежним фактором гіршого прогнозу виживаності [26, 29].

У жінок відзначають вищий ризик рецидиву, прогресування хвороби та смерті після радикального лікування [5, 10-12, 24, 29, 31]. Прогнози виживаності гірші також серед пацієнтів жіночої статі. Виживаність через 5 років після встановлення діагнозу у жінок порівняно з чоловіками становить для стадії I 93,7 проти 96,5\%, для стадії II - 59,6 проти 65,5\%, для стадії III - 49,6 проти 58,8\%, для стадії IV - 15,2 проти $27,1 \%$ [18]. Проте в інших публікаціях ситуація із захворюваністю жінок на РСМ представлена більш оптимістично [1, 8 , 20]. Зокрема, R. Pichler та співавтори вказали, що жіноча стать не $€$ причиною гіршого прогнозу виживаності, але $€$ фактором розвитку місцево-поширеного РСМ (стадія рТ3) та виконання гетеротопічного відведення сечі після радикальної цистектомії. У цій вибірці хворих після радикальної цистектомії результати 5-річної загальної виживаності для стадій I, II, III були 68,1; 40,2; 35,8\% відповідно. Для хворих з метастатичним ураженням лімфатичних вузлів канцерспецифічна 5-річна виживаність була $36 \%$ у порівнянні з 64,6\% у хворих без ураження лімфатичних вузлів [21].

Результати нашого дослідження вказують на те, що показники 5-річної виживаності жінок з діагнозом низькодиференційованого РСМ кращі, ніж у чоловіків, окрім стадії I, де вибірка хворих була малою. У порівнянні з даними літератури, наведеними вище, результати виживаності жінок в нашій групі дослідження, зокрема при стадіях II, III та IV, $€$ подібними або кращими за результати, представлені іншими дослідниками, навіть незважаючи на те, що для аналізу були вибрані дані хворих на найагресивнішу форму РСМ, низькодиференційовану.

У більшості країн світу канцерспецифічна летальність, викликана РСМ серед жінок, є вищою за таку в чоловіків [5]. Таким чином, жіноча стать розглядається як фактор несприятливого прогнозу виживаності у хворих на РСМ. Відношення канцерспецифічної летальності, спричиненої РСМ, до захворюваності на рак у чоловіків є нижчим, ніж у жінок [27]. Результати нашого дослідження вказують, навпаки, що це співвідношення для захворілих жінок є 0,53 , для чоловіків $-0,68$.

Дані літератури вказують, що жінки переважать чоловіків за часткою місцево-поширеного РСМ [7, 13, 21, 22, 30, 31]. Згідно з нашими результатами, з підвищенням стадії низькодиференційованого РСМ частка захворілих жінок зменшується. Виживаність при всіх стадіях РСМ серед жінок є вищою, ніж серед чоловіків, хоча статистично достовірної різниці досягнуто лише для стадії IV.

\section{ВИСНОВКИ}

1. Захворюваність на низькодиференційований РСМ має чітку гендерну залежність від стадії раку в бік переважання чоловічого фактора зі співвідношенням захворілих чоловіків до жінок як 5,2:1. 3 підвищенням клінічної стадії раку вона стає ще більшою. При І стадії співвідношення чоловіків до жінок є 2,7:1, при II стадії - 4,6:1, при III стадії - 5,7:1, при IV стадії - 8,1:1.

2. Результати 5- та 10-річної виживаності жінок з низькодиференційованим РСМ кращі, ніж серед чоловіків. При проведенні аналізу виживаності за методом Каплана - Мейєра серед чоловіків і жінок залежно від клінічної стадії низько- диференційованого РСМ виявлена статистично значима відмінність лише між кривими виживаності хворих зі стаді$€ ю$ IV в бік кращої виживаності жінок $(p=0,035)$.

3. При проведенні аналізу виживаності за методом Каплана - Мейєра серед чоловіків і жінок залежно від методу хірургічного лікування статистично значимих відмінностей між кривими виживаності виявлено не було. Збільшення вибірки хворих, особливо за рахунок пацієнтів жіночої статі, зможе підвищити точність аналізу.

\section{СПИСОК ВИКОРИСТАНОЇ ЛІТЕРАТУРИ}

1. Andreassen, B. K., Grimsrud, T. K., \& Haug, E. S. (2018). Bladder cancer survival: Women better off in the long run. Eur $J$ Cancer, 95, 52-58. doi: 10.1016/j.ejca.2018.03.001.

2. Cohn, J. A., Vekhter, B., Lyttle, C., Steinberg, G. D., \& Large, M. C. (2014). Sex disparities in diagnosis of bladder cancer after initial presentation with hematuria: a nationwide claims-based investigation. Cancer, 120(4), 555-561. doi: $10.1002 /$ cncr.28416.

3. Dietrich, K., Demidenko, E., Schned, A., Zens, M. S., Heaney, J., \& Karagas, M. R. (2011). Parity, early menopause and the incidence of bladder cancer in women: a case-control study and meta-analysis. Eur J Cancer, 47(4), 592-599. doi: 10.1016/j.ejca.2010.10.007.

4. Dobruch, J., Daneshmand, S., Fisch, M., Lotan, Y., Noon, A. P., Resnick, M. J., Boorjian, S. A. (2016). Gender and Bladder Cancer: A Collaborative Review of Etiology, Biology, and Outcomes. Eur Urol, 69(2), 300-310. doi: 10.1016/j.eururo.2015.08.037.

5. Donsky, H., Coyle, S., Scosyrev, E., \& Messing, E. M. (2014). Sex differences in incidence and mortality of bladder and kidney cancers: national estimates from 49 countries. Urol Oncol, 32(1), 40.e23-31. doi: 10.1016/j.urolonc.2013.04.010.

6. Edge S. B., Byrd D. R., Compton C. C, Fritz A. G, Greene F. L, \& Trotti, A. (Eds.) (2010). AJCC cancer staging manual $\left(7^{\text {th }}\right.$ ed). New York, NY: Springer.

7. Fajkovic, H., Halpern, J. A., Cha, E. K., Bahadori, A., Chromecki, T. F., Karakiewicz, P. I..... Shariat, S. F. (2011). Impact of gender on bladder cancer incidence, staging, and prognosis. World J Urol, 29(4), 457-463. doi: 10.1007/s00345-011-0709-9. 8. Heberling, U., Koch, R., Hübler, M., Baretton, G. B., Hakenberg, O. W., Wirth, M. P., \& Froehner, M. (2018). Gender and Mortality after Radical Cystectomy: Competing Risk Analysis. Urol Int, 101(3), 293-299. doi: 10.1159/000487445.

9. Witjes (Chair), J. A., Bruins, M., Cathomas, R., Compérat, E., Cowan, N.C., Gakis, G.... Veskimäe, E. (Eds.) (2019). Muscle-invasive and Metastatic Bladder Cancer. EAU Guidelines. Edn. presented at the EAU Annual Congress Barcelona: EAU Guidelines Office, Arnhem, The Netherlands.

10. Kluth, L. A., Fajkovic, H., Xylinas, E., Crivelli, J. J., Passoni, N., Rouprêt, M., Shariat, S. F. (2013). Female gender is associated with higher risk of disease recurrence in patients with primary T1 high-grade urothelial carcinoma of the bladder. World J Urol, 31(5), 1029-1036. doi: 10.1007/s00345-012-0996-9.

11. Kluth, L. A., Rieken, M., Xylinas, E., Kent, M., Rink, M., Rouprêt, M. Shariat, S. F. (2014). Gender-specific differences in clinicopathologic outcomes following radical cystectomy: an international multi-institutional study of more than 8000 patients. Eur Urol, 66(5), 913-919. doi: 10.1016/j.eururo.2013.11.040.

12. Krimphove, M. J., Szymaniak, J., Marchese, M., Tully, K. H., D'Andrea, D., Mossanen, M.,... Trinh, Q. D. (2019). Sex-specific Differences in the Quality of Treatment of Muscle-invasive Bladder Cancer Do Not Explain the Overall Survival Discrepancy. Eur Urol Focus, Jun 18. doi: 10.1016/.j.euf.2019.06.001.

13. Liu, S., Yang, T., Na, R., Hu, M., Zhang, L., Fu, Y.,... Ding, Q. (2015). The impact of female gender on bladder cancer-specific death risk after radical cystectomy: a meta-analysis of 27,912 patients. Int Urol Nephrol, 47(6), 951-958. doi: 10.1007/s11255-015-0980-6.

14. Madeb, R., \& Messing, E. M. (2004). Gender, racial and age differences in bladder cancer incidence and mortality. Urol Oncol, 22(2), 86-92. doi: 10.1016/S1078-1439(03)00139-X.

15. Marks, P., Soave, A., Shariat, S. F., Fajkovic, H., Fisch, M., \& Rink, M. (2016). Female with bladder cancer: what and why is there a difference? Transl Androl Urol, 5(5), 668-682. doi: 10.21037/tau.2016.03.22.

16. Messer, J. C., Shariat, S. F., Dinney, C. P., Novara, G., Fradet, Y., Kassouf, W. ... Svatek, R. S. (2014). Female gender is associated with a worse survival after radical cystectomy for urothelial carcinoma of the bladder: a competing risk analysis. Urology, 83(4), 863-867. doi: 10.1016/j.urology.2013.10.060.

17. Mitra, A. P., Skinner, E. C., Schuckman, A. K., Quinn, D. I., Dorff, T. B., \& Daneshmand, S. (2014). Effect of gender on outcomes following radical cystectomy for urothelial carcinoma of the bladder: a critical analysis of 1,994 patients. Urol Oncol, 32(1), 52. e51-59. doi: 10.1016/j.urolonc.2013.08.007.

18. Mungan, N. A., Kiemeney, L. A., van Dijck, J. A., van der Poel, H. G. \& Witjes, J. A. (2000). Gender differences in stage distribution of bladder cancer. Urology, 55(3), 368-371.

19. Oken, M. M., Creech, R. H., Tormey, D. C., Horton, J., Davis, T. E., McFadden, E. T., \& Carbone, P. P. (1982). Toxicity and response criteria of the Eastern Cooperative Oncology Group. Am J Clin Oncol, 5(6), 649-655.

20. Patafio, F. M., Robert Siemens, D., Wei, X., \& Booth, C. M. (2015). Is there a gender effect in bladder cancer? A population-based study of practice and outcomes. Can Urol Assoc J, 9(7-8), 269-274. doi: 10.5489/cuaj.2927. 
21. Pichler, R., Fritz, J., Heidegger, I., Oberaigner, W., Horninger, W., \& Hochleitner, M. (2017). Gender-related Outcome in Bladder Cancer Patients undergoing Radical Cystectomy. J Cancer, 8(17), 3567-3574. doi: 10.7150/jca.21130.

22. Puente, D., Malats, N., Cecchini, L., Tardón, A., García-Closas, R. Serra, C.,... Investigators, E. S. G. (2003). Gender-related differences in clinical and pathological characteristics and therapy of bladder cancer. Eur Urol, 43(1), 53-62. doi: 10.1016/s0302-2838(02)00496-7.

23. Scosyrev, E., Noyes, K., Feng, C., \& Messing, E. (2009). Sex and racial differences in bladder cancer presentation and mortality in the US. Cancer, 115(1) 68-74. doi: 10.1002/cncr.23986

24. Seo, M., \& Langabeer li, J. R. (2018). Demographic and Survivorship Disparities in Non-muscle-invasive Bladder Cancer in the United States. J Prev Med Public Health, 51(5), 242-247. doi: 10.3961/jpmph.18.092.

25. Shariat, S. F., Karakiewicz, P. I., Palapattu, G. S., Lotan, Y., Rogers, C. G., Amiel, G. E.,... Lerner, S. P. (2006). Outcomes of radical cystectomy for transitional cell carcinoma of the bladder: a contemporary series from the Bladder Cancer Research Consortium. J Urol, 176(6 Pt 1), 2414-2422; discussion 2422. doi: 10.1016/j.juro.2006.08.004.

26. Shariat, S. F., Sfakianos, J. P., Droller, M. J., Karakiewicz, P. I., Meryn, S., \& Bochner, B. H. (2010). The effect of age and gender on bladder cancer: a critical review of the literature. BJU Int, 105(3), 300-308. doi: 10.1111/j.1464-410X.2009.09076.x.

27. Siegel, R. L., Miller, K. D., \& Jemal, A. (2019). Cancer statistics, 2019. CA Cancer J Clin, 69(1), 7-34. doi: 10.3322/caac.21551.

28. Soave, A., Dahlem, R., Hansen, J., Weisbach, L., Minner, S., Engel, O.,... Rink, M. (2015). Gender-specific outcomes of bladder cancer patients: a stage-specific analysis in a contemporary, homogenous radical cystectomy cohort. Eur J Surg Oncol, 41(3), 368-377. doi: 10.1016/j.ejso.2014.03.003

29. Soave, A., Schmidt, S., Dahlem, R., Minner, S., Engel, O., Kluth, L. A., ,.. Rink, M. (2015). Does the extent of variant histology affect oncological outcomes in patients with urothelial carcinoma of the bladder treated with radical cystectomy? Urol Oncol, 33(1), 21.e21-21.e29. doi: 10.1016/j.urolonc.2014.10.013.

30. Stenzl, A. (2010). Words of wisdom. Re: sex and racial difference in bladder cancer presentation and mortality in the US. Eur Urol, 57(4), 729. doi: 10.1016/j.eururo.2010.01.030

31. Uhlig, A., Seif Amir Hosseini, A., Simon, J., Lotz, J., Trojan, L., Schmid, M., \& Uhlig, J. (2018). Gender Specific Differences in Disease-Free, Cancer Specific and Overall Survival after Radical Cystectomy for Bladder Cancer: A Systematic Review and Meta-Analysis. J Urol, 200(1), 48-60. doi: 10.1016/j.juro.2017.11.150.

\section{Женский пол как фактор прогноза выживаемости больных после хирургического лечения низкодифференцированного рака мочевого пузыря}

П.Г. Яковлев ${ }^{1}$, Д.А. Клюшин ${ }^{2}$

${ }^{1}$ Национальный медицинский университет имени А.А. Богомольца, Киев

${ }^{2}$ Киевский национальный университет имени Т.Г. Шевченко, Киев

Резюме. Рак мочевого пузыря - злокачественное новообразование, преимущественно отмечаемое у населения мужского пола. Однако считается, что у женщин это заболевание протекает более агрессивно и результаты выживаемости хуже, чем у мужчин. Цель. Определить гендерные отличия в заболеваемости агрессивной формой рака мочевого пузыря, низкодифференцированным раком, и показатели выживаемости больных обоего пола в зависимости от клинической стадии болезни и метода проведенного радикального хирургического лечения. Материалы и методы. Ретроспективный анализ историй болезней 364 пациентов с низкодифференцированным раком мочевого пузыря (мужчин 305, женщин 59, соотношение мужчин и женщин - 5,2:1), которые проходили хирургическое лечение в 2004-2017 гг. с целью выявления статистически значимой корреляции между полом пациента и результатами выживаемости в зависимости от клинической стадии болезни (I, II, III и IV) и метода хирургического лечения (трансуретральная резекция, резекция, радикальная цистэктомия). Результаты. С увеличением клинической стадии рака количество заболевших женщин уменьшается обратно пропорционально стадии рака с соотношением заболевших мужчин и женщин 5,2:1. Запущенных случаев рака среди женщин не было. Выявлена статистически значимая и достоверная разница между кривыми выживаемости больных с IV стадией низкодифференцированного рака мочевого пузыря ( $p=0,035)$ в сторону лучшей выживаемости женщин. При раке I стадии и проведении трансуретральной резекции мочевого пузыря различий между кривыми выживаемости как визуально, так и на основании статистических расчетов $(p=0,738)$ нет. При стадиях II, III и при проведении резекции мочевого пузыря и радикальной цистэктомии кривые выживаемости женщин выше таковых у мужчин, критерий $p$ приближается к порогу значимости $(p=0,102)$. Увеличение выборки больных, особенно за счет пациентов женского пола, сможет улучшить точность анализа. Выводы. Заболеваемость низкодифференцированным раком мочевого пузыря и смертность вследствие него имеет четкую зависимость в аспекте пола пациента от стадии рака в сторону преобладания мужского фактора. Результаты 5- и 10-летней выживаемости женщин с низкодифференцированным раком мочевого пузыря лучше по сравнению с мужчинами. При проведении анализа выживаемости по методу Каплана - Мейера в зависимости от клинической стадии низкодифференцированного рака мочевого пузыря и метода хирургического лечения выявлена статистически значимая разница лишь между кривыми выживаемости больных с IV стадией в сторону лучшей выживаемости женщин. При других стадиях и методах лечения кривые выживаемости женщин выше таковых у мужчин, однако статистической значимости эти различия не имели.

Ключевые слова: рак мочевого пузыря, низкодифференцированный рак, хирургическое лечение, выживаемость, гендерные отличия.

\section{Female gender as a survival prognostic factor in patients with high-grade bladder cancer after surgical treatment \\ P.G. Yakovlev' ${ }^{\text {, D.A. Klyushin }}{ }^{2}$ \\ 'Bogomolets National Medical University, Kyiv ${ }^{2}$ Shevchenko Kyiv State University, Kyiv}

Summary. Bladder cancer is a malignancy with prevalent in cadence amongmales. Nevertheless, females are considered the ones with more aggressive, more advanced at the diagnosis disease with worse survival rates than males. Aim. To determine the gender differences in incidence of high-grade bladder cancer, and survival depending on clinical stage of the cancer and method of surgical treatment. Materials and methods. Retrospective study of 364 patients with high-grade bladder cancer (males 305, females 59 , ratio $=5.2: 1$ ) surgically treated in 2004-2017 to reveal statistically significant correlation between gender and survival depending on clinical stage of the cancer (I, II, III, IV) and method of surgical treatment (transurethral resection, partial cystectomy, radical cystectomy). Results. We found that the higher the clinical stage of high-grade bladder cancer, the less is the incidence of cancer among females. There were no cases of advanced cancer not amenable to surgical treatment among females. Statistically significant difference was determined between survival curves of patients Stage IV in favor of female patients $(p=0,035)$. In Stage I patients of both sexes and after transurethral resection there were no differences in survival $(p=0,738)$. In Stages II, III, and after partial or radical cystectomy the survival curves of females were higher than of males, but difference was not statistically significant $(p=0,102)$. Expanding the pool of female patients might improve the accuracy of the statistical analysis. Conclusions. Incidence of and mortality from high grade bladder cancer is predominant among males, rises even higher in advanced stages of cancer. The outcomes of 5- and 10 -year overall survival in females with high-grade disease are better in females. Statistically significant better survival was demonstrated in females with Stage IV high-grade bladder cancer. In other stages and after any surgical method of treatment the survival of females is better, but results were not statistically significant.

Key words: bladder cancer, high-grade cancer, surgical treatment, survival, gender difference.

Aдреса:

Яковлев Павло Георгійович

01601, Київ, бульв. Шевченка, 13

Національний медичний університет імені О.О. Богомольия

E-mail:pavel_3@hotmail.com 